\title{
Spanish National Hip Fracture Registry (SNHFR): a description of its objectives, methodology and implementation.
}

Registro Nacional Español de Fracturas de Cadera (RNFC): descripción de sus objetivos, metodología e implementación.

Sáez-López $\mathrm{P}^{1,3}$, González-Montalvo JI ${ }^{2,3}$, Ojeda-Thies $\mathrm{C}^{4}$, Mora-Fernández $\mathrm{J}^{5}$, MuñozPascual $\mathrm{A}^{6}$ Cancio $\mathrm{JM}^{7}$, Tarazona $\mathrm{FJ}^{8}$, Pareja $\mathrm{T}^{9}$, Gómez-Campelo $\mathrm{P}^{3}$, Montero-Fernández $\mathrm{N}^{10}$, Alarcón $\mathrm{T}^{2,3}$, Mesa Lampre $\mathrm{P}^{11}$, Larrainzar $\mathrm{R}^{12}$, Duaso $\mathrm{E}^{13}$, Gil-Garay $\mathrm{E}^{2,3}$, Diéz-Pérez $\mathrm{A}^{14}$, Prieto Alhambra $\mathrm{D}^{15}$, Queipo-Matas $\mathrm{R}^{3,16}$ Otero-Puime $\mathrm{A}^{3,17}$ on behalf of the participants in the RNFC*.

${ }^{1}$ Hospital Universitario Fundación Jiménez Díaz. Madrid.

${ }^{2}$ Hospital Universitario La Paz. Madrid.

${ }^{3}$ Instituto de Investigación del Hospital La Paz. IdiPAZ. Madrid

${ }^{4}$ Hospital Universitario 12 de Octubre. Madrid.

${ }^{5}$ Hospital Clínico Universitario San Carlos. Madrid.

${ }^{6}$ Complejo Asistencial de Segovia.

${ }^{7}$ Hospital de Badalona. Barcelona.

${ }^{8}$ Hospital de La Ribera. Alzira.

${ }^{9}$ Hospital Universitario de Guadalajara. Guadalajara.

${ }^{10}$ Hospital Universitario Gregorio Marañón. Madrid

${ }^{11}$ Hospital Nuestra Señora de Gracia. Zaragoza.

${ }^{12}$ Hospital Infanta Leonor. Madrid.

${ }^{13}$ Hospital de Igualada. Barcelona.

${ }^{14}$ Hospital del Mar. Barcelona. CIBER de Fragilidad y Envejecimiento Saludable, Instituto Carlos III.

${ }^{15}$ G Associate Professor \& NIHR Clinician Scientist. NDORMS, University of Oxford. Grupo de Investigación GREMPAL, Idiap Jordi Gol y CIBERFes; Universitat Autònoma de Barcelona e Instituto de Salud Carlos III, Barcelona.

${ }^{16}$ Departamento de Farmacia y Biotecnología. Facultad de Medicina. Universidad Europea de Madrid

${ }^{17}$ Departamento de Medicina Preventiva y Salud Pública. Universidad Autónoma de Madrid. Madrid.

(*Listado de nombres al final del artículo)

Autor para correspondencia: Juan I González Montalvo. Servicio de Geriatría, Hospital Universitario La Paz. Madrid, Spain. E-mail: juanignacio.gonzalez@ salud.madrid.org 


\begin{abstract}
.
Objective: To ascertain the current situation and clinical variability of the provision of care for Hip Fracture (HF) in Spain and the factors related to it by using a National Registry (NHFR) with high patient numbers and territorial representation (NHFR), and to compare results on a national and international level and propose standards and criteria to improve healthcare quality.

Design: Continuous registry for at least three years of a representative sample of patients admitted to Spanish hospitals due to HF using the Minimum Common Dataset international Fragility Fracture Network (FFN) MCD, adapted for Spanish.
\end{abstract}

Study scope and subjects: all patients over the age of 74 years who are hospitalized with a diagnosis of a fagility HF at the participating hospitals distributed throughout the Spanish territory. Initially 48 hospitals are included, and we expect to incorporate the highest number of sites possible.

Results: It is expected to ascertain the current situation of provision of care for HF in Spain. Each hospital will be offered information regarding their results and their situation compared to the rest. The results from national hospitals will be compared to others included in the registry and to hospitals abroad, which use the same database. Variability will be studied, care standards will be established, and objectives will be proposed for the continuous improvement of the care process of this condition.

\title{
Resumen.
}

Objetivo: Conocer la situación actual y la variabilidad clínica del proceso asistencial a la Fractura de Cadera (FC) en España y los factores relacionados con la misma mediante la utilización de un Registro Nacional (RNFC) con elevada casuística y representación territorial (RNFC), así como comparar resultados en el ámbito nacional e internacional y proponer estándares y criterios para mejorar la calidad asistencial.

Diseño: Registro continuo durante al menos tres años de una muestra representativa de los pacientes ingresados por FC en los hospitales españoles mediante el Minimum Common Dataset - MCD internacional de la Fragility Fracture Network (FFN) adaptado al castellano.

Ámbito y sujetos del estudio: se incluirán todos los pacientes mayores de 74 años hospitalizados con el diagnóstico de FC por fragilidad en los hospitales participantes repartidos por el territorio español. Inicialmente están incluidos 48 hospitales, a los que se espera que se vayan incorporando el mayor número posible de centros.

Resultados: Se pretende conocer la situación actual de la atención a este proceso en España Se ofrecerá a cada hospital la información de sus resultados y su situación en relación al resto, se compararán los resultados de los hospitales nacionales entre sí y con los hospitales extranjeros incluidos en registros que usan la misma base de datos. Se estudiará la variabilidad, se establecerán estándares asistenciales y se plantearán objetivos para la mejora continua del proceso en la atención a esta patología. 


\section{Rationale}

Hip fracture (HF) is one of the main health problems associated with ageing and frailty. It has serious repercussions regarding morbidity and mortality, with a considerable number of patients developing functional dependence and an increase in institutionalization (1-3). According to statistical data from the Spanish Ministry of Health, the incidence in 2008 in Spain was 103.76 cases per 100,000 inhabitants. The rate increases for those over 75 years of age, up to to 2,534 cases per 100,000 inhabitants for the age group 90-94 years of age (3). An incidence of approximately 40,000 to 45,000 hip fractures has recently been calculated per year in Spain, the care of which involves an annual cost of 1,591 million Euros and a loss of 7,218 quality-adjusted life-years (4,5). The incidence is expected to continue to increase in the near future, especially among people over the age of 80 years (5).

Some factors in the care process of HF are known to influence its evolution and patients' clinical results. Thus, issues such as delay in surgical intervention, lack of prevention and treatment of medical problems or the lack of early rehabilitation, lead to a deterioration in the clinical course of patients and an increase in the final costs of the process (6).

Advances in terms of surgical technique, types of anaesthesia, perioperative care, early rehabilitation and working in multidisciplinary teams have improved the clinical results $(6,7)$. Nevertheless, the rates of mortality and of functional decline secondary to this type of fracture continue to be very high.

In recent years, several articles and Clinical Practice Guidelines (CPG) have been published with recommendations that have enabled better care of and agreement around this condition (8-12). As has occurred previously in Great Britain with the publication of the Blue Book shared by several scientific societies of professionals who care for patients with hip fracture (13), the Clinical Practice Guidelines in Geriatrics for the Elderly Affected by Hip Fracture was published in Spain in 2007 in collaboration with the Spanish Society of Geriatrics and Gerontology and the Spanish Society of Orthopaedic Surgery and Traumatology (SEGG and SECOT; Spanish acronyms), as well as another CPG released in 2012 endorsed by the Spanish Association of Osteoporotic Fractures (SEFRAOS; Spanish acronym) $(14,15)$. But there has been no follow-up regarding their implementation in Spanish hospitals, and the data available regarding clinical variability in the care of this 
process show large variability; for example, surgical delay, length of hospital stay, number of rehabilitation sessions, availability of referral to a functional recovery unit, number of physician follow-up visits or osteoporosis treatment rates, among other aspects $(4,16,17)$.

In several countries, national registries have been set up for patients with HF. Among these, the most relevant are those undertaken in England, Scotland and Australia. These experiences and others have been summarised in recent publications, observing that in the countries in which a HF registry has been undertaken, the care process has been audited as a result, inspecting whether it adheres to or deviates from the quality standards established and introducing corrective measures to improve the care process and efficiency $(18,19)$. For example, after the implementation of the National Hip Fracture Database (NHFD) in England, from 2007 to 2011 the percentage of patients who received surgery in the first 48 hours after admission increased from $54.5 \%$ to $71.3 \%$, mortality after 30 days decreased from $10.9 \%$ to $8.5 \%$ and early orthogeriatric intervention in patients admitted due to HF increased from $48 \%$ to $90.2 \%$ (20). Regarding efficiency, there was also a reduction in hospital stay (which is the process phase with the greatest consumption of resources) and in institutionalization after discharge following implementation of the British NHFD registry. A recent external evaluation has even shown an improvement in survival after 30, 90 and 365 days (20).

Therefore, the information provided by these registries is important for doctors and for managers. Establishing and studying these registries provides an opportunity to work together auditing the process, detecting any possible weaknesses in our services, identifying areas for improvement, and monitoring the impact of changes in clinical results and in management.

In Spain, there have previously been registries and multicentre studies of great interest.

In the community of Castilla y León, supported by the respective regional scientific societies of Geriatrics and Gerontology and of Orthopaedic Surgery and Traumatology, orthogeriatric collaboration was assessed in the care of patients with HF admitted to 14 public hospitals in 2013 (17); and subsequently, in 2014 and 2015, a temporary registry of hip fractures was developed for 2 months each year in the same hospitals. Currently, this registry has 776 cases; the main findings have recently been published (21).

In recent years, a multicentre study called SPARE-HIP was completed, endorsed by the Spanish Society of Osteoporotic Fractures (SEFRAOS; Spanish acronym), which 
involved studying a cohort of 30 cases of hip fracture each in 45 Spanish hospitals (22). Its goal was to obtain a partial sample representative of the national territory.

Lastly, Caeiro et al. recently published another multicentre study that included 487 patients with HF admitted consecutively in 28 hospitals in 6 autonomous communities in Spain, in order to find out the social and economic burden associated to fracture during hospitalization and 12 months afterwards (16).

These registries are clearly of great interest because, although each provides only a partial picture, they compile considerable numbers of patients cared for at multiple sites in the Spanish territory and provide valuable information.

Regarding the above, the National Hip Fracture Registry (NHFR; RNFC, Spanish acronym), which is currently under way, proposes improving some aspects, namely, 1) consecutively including all patients diagnosed with $\mathrm{HF}$ at each participating hospital in a continuous registry and 2) obtaining a comprehensive sample that can epidemiologically ensure representativeness on a national level, with a final vocation for including all patients with HF who are hospitalized in the country. 


\section{Objectives}

The main objective of the NHFR is to ascertain the demographic, clinical, surgical, functional and care-based characteristics of hip fracture patients throughout the Spanish territory, during hospitalization and up to one month after hospital discharge, analyse the presence and magnitude of the existing clinical variability and establish measures to improve care quality.

The secondary or specific objectives are:

-To ascertain the care model for the HF process in Spain and the variability in clinical practice between participating hospitals.

-To facilitate the evaluation of each site's results in terms of health and recovery of functional capacity for their patients.

-To audit practice comparing it to the recommendations of the current Clinical Practice Guidelines.

-To compare the results among the different participating Spanish hospitals with those of foreign hospitals included in the Fragility Fracture Network (FFN) database.

-To disclose the results among different participating hospitals and communicate them to the healthcare authorities and administrations.

- To establish explicit criteria for good in-process practices and results, define the indicators for their measurement, and propose concrete standards to be attained that specify excellent compliance to said indicators in order to improve care quality, with imitation of best practice at the level of each hospital, as well as regionally and nationally.

- To periodically audit the results obtained in the improvement of the process after implementing the registry and in the measures proposed seeking continuous improvement in care quality. 


\section{Method}

The registry will consist of a multicentre, observational, descriptive study of the epidemiological, clinical and care characteristics obtained during admission, inpatient evolution and one month after experiencing a HF due to fragility in a representative sample of, initially, 48 Spanish hospitals in the National Health Service network (Annex 1).

The inclusion criteria are: having been admitted to one of the participating hospitals with the diagnosis of hip fracture due to fragility (due to a fall from standing height), being older than 74 years of age ( 75 years or older) and understanding and signing an informed consent (by the patient or their next of kin).

The exclusion criterion is any HF occurring as a result of high energy trauma as well as pathologic fractures due to cancer.

The variables to be collected include (Table 1): age, gender, hospital, autonomous community, dates of admissions, surgery and hospital discharge, place of residence prior to admission, at discharge and at one month, prefracture patient mobility and mobility one month postfracture, cognitive status at the time of admission (Pfeiffer Questionnaire), calcium and vitamin D supplements, and anti-osteoporosis medication (antiresorptive and osteoforming drugs) prescribed to the patient prior to the fracture, at hospital discharge and after one month, the type of fracture, the type of surgical intervention performed, the anaesthetic risk (ASA Classification), the type of anaesthesia used during surgery, the appearance of pressure ulcers during hospitalization, their vital status at the time of hospital discharge and after one month, the involvement of a clinical physician in addition to a specialist in Orthopaedic Surgery and Traumatology, early postoperative mobilization (in the first 24 hours after the intervention), the length of hospital stay, surgical delay, as well as the the existence of surgical readmissions and surgical re-interventions in the month following the fracture.

Data collection will be conducted using the Spanish version of the Fragility Fracture Network registry (FFN Minimum Common Dataset - MCD). The FFN (Fragility Fracture Network) is an international organization that aims to achieve maximum functional recovery and quality of life for people who have suffered an osteoporotic fracture, as well as secondary prevention through the global optimization of the multidisciplinary management of this health problem. Its activities include the creation of a network encompassing the greatest number of countries possible and the creation of Consensus Guidelines, thus establishing quality standards and systematically measuring their 
application. Within the FFN, in 2013 members of an international working group composed mainly by representatives of other previously existing national registries, proposed a Minimum Common Dataset (FFN-MCD) with three important characteristics: it was concise, it covered the key elements of the casemix, care and results, and it was compatible with already existing databases (23).

Data collection will take place in two phases. In the hospital phase, the data corresponding to baseline status and those referring to the process until the time of discharge will be collected by the physician in charge of the patient. In the post-discharge phase, data will be collected one month after the fracture by telephone interview or at a follow-up visit by the corresponding professional.

There will be a representative at each participating hospital as the local person in charge of the registry, responsible for sending data and safeguarding it. The people in charge of each site will provide data on a quarterly basis for all the patients treated for a hip fracture at their hospital, including follow-up one month after discharge. The deadline for data inclusion will end 4 weeks after the end of each quarter. The data sent will be encrypted, and entered into an online platform for their analysis.

A data manager will be in charge of assembling the data from all the hospitals, assigning an identifier to each site that includes the autonomous community of origin, data clean-up, performing descriptive analyses and the pertinent associations, drafting global quarterly reports (of all the cases provided by the group of hospitals) and global annual and partial reports (by autonomous communities, ACs).

Reports will be sent to the people in charge at each hospital, to the representatives of the registry for each $\mathrm{AC}$, to the scientific societies that endorse it and to the sponsors.

\section{Project Timeline (Figure 1)}

1. Year prior to Registry (already performed). Includes the definition of the project, performing and publishing a literature review of the background of the subject, the adaptation of the FFN Database, coordination with the chairpersons in charge of the FFN registry, request for endorsements by Scientific Societies, the inclusion of hospitals and approval by Institutional Review Boards (IRBs), classification of the study by the Spanish Agency of Medicines and Medical Devices (AEMPS), request for support from the Ministry of Health (General Sub-Directorate of Health Planning), registry at the Spanish 
Agency of Data Protection, and the integration of the Project in a Research Institute as the coordinating site (Hospital Universitario La Paz Research Institute: IdiPAZ).

\section{First year of Registry:}

During the first quarter, it is planned to hire Technical Secretary and Data Manager, and to carry out the Pilot study at 15 hospitals, and follow up with the collection of continuous data at the hospitals.

In the second half of the year, data analysis should be carried out for the first 6 months, and the first results are to be reported at national and international scientific meetings.

\section{Second and third year of the Registry:}

After the first complete year, it is planned to carry out an annual analysis of the recorded data, as well as an analysis of clinical variability in this period; care quality standards, criteria and indicators are to be defined, updated ald followed up. Data will be compared periodically among the ACs and compared to international data, and the agreed-upon standards and results obtained thoughout the process of continuous quality improvement will be published. Starting in the second year, a request will be elevated to the Ministry of Health for the Registry to be considered as an Information Source of Health Interest.

\section{Data analysis and exploitation:}

1. Numeric and graphic descriptive statistics will be performed for the data from each participating hospital compared to the group and, annually, for the data grouped for each Autonomous Community and for all the cases nationally. The descriptive statistics of each variable will use the mean (and standard deviation) or the median (and interquartile ranges) for the ordinal variables and the percentage for the qualitative variables.

2. A statistical analysis of variability will be carried out among sites: Comparison of indicators using the Variation Rate (VR75-25) and Standardized Utilization Rate (SUR).

3. The following are considered to be quality criteria for the definition of standards: presurgical stay (hours), overall length of stay (days), percentage of patients managed surgically in the first 48 hours, percentage of patients who mobilised in the first 24 hours after surgery, percentage of patients treated during hospitalization by a clinical physician, percentage of patients who develop pressure ulcers, percentage of patients discharged with antiosteoporosis treatment (secondary fracture prevention), mortality rate during hospital 
admission and one month after the fracture, degree of independence for ambulation one month after the fracture, percentage of patients referred to functional recovery units, percentage of patients with a new institutionalization (admission to a nursing home among patients who previously lived in their home).

4. The investigators will propose quality standards based on the results of the hospitals with the best practices (benchmarking) and the Clinical Practice Guidelines and other international registries.

5. The quality thresholds will be expressed as a percentage of cases of each hospital that should comply with each of these standards.

\section{Results analysis timeline:}

The following will be performed during the first year:

1. Procurement of the results of the variables at each hospital, each autonomous community and at a national level.

2. Comparison of the results with the rest of the countries participating in the international Fragility Fracture Network registry.

3. Definition of national standards and target-setting.

During the second and third year, the annual analyses described will be performed and, additionally,

4. Comparison of the annual evolution of each hospital for each one of the indicators established, assessment of each hospital's internal capacity for improvement.

5. Assessment whether the implementation of the NHFR is able to improve the care process of fragility Hip Fractures in the elderly. 


\section{Limitations and strengths of the NHFR}

The limitations of the Registry may be conditioned by the inherent nature of the study, namely, data collection by the healthcare professional who cares for the patient, which could introduce biases on the one hand, but on the other also provide added clinical value regarding other databases, such as administrative ones (18). For pragmatic and economic reasons, this is the manner in which data collection is being carried out in the international registries currently under way as, otherwise, costs for the project would be greatly increased. It is unclear whether this fact may interfere negatively (because of the aforementioned bias) or positively (by generating a quest for improvement in regular clinical activity). To minimize this possible bias, direct procurement of information electronically will be promoted whenever possible through hospital activity records and subsequently some variables available will be checked in the CMDB.

Another limitation is financial dependence to guarantee continued viability of the Project; although no financial compensation is foreseen neither for the professionals who provide their cases, nor for the people in charge at each hospital or for the investigating team, it will be necessary to hire some professionals such as a data manager and technical secretary.

The general strengths include the continuity of the registry, as it will include all the patients hospitalized due to $\mathrm{HF}$ at each participating hospital, and their demographic representativeness, ensured by the large number of hospitals participating from the start and the desire to increase the number of hospitals.

The strengths inherent to the study include the prior experience of the investigative team in the area approached by the Registry, specifically their professional achievement in multidisciplinary coordinated treatment units (Co-managed care) for the care of patients with hip fracture, the prior experience in the study and casemix analysis of hospital cohorts of patients with hip fracture, the prior experience in coordination, start-up and results analysis of the aforementioned Multicentre Hip Fracture Registries, albeit more limited at a national level, the previous experience of the team of epidemiologists in the initiation of longitudinal demographic epidemiological studies in the elderly population, the recognition by the International Osteoporosis Foundation (IOF) of six of the Orthogeriatric units where research team members work as sites with Best Practices in Fractures Liaison Services (FLS) in Hip Fracture, the scientific and educational contribution of the investigative team, specifically regarding the subject of hip fracture, which can be quantified in a total of 36 indexed articles on PubMed regarding aspects related to HF in 
the elderly, in addition to several Doctoral Theses and a multitude of communications at congresses. In addition to its own team of investigators, the project includes the support of external "advisers" for assessment and methodological support by professionals of renowned prestige who have had responsibilities and accumulated experience through other hip fracture registries, in addition to unite, to date, a total of 48 hospitals for the Project.

The extrinsic strengths of the project include the following:

- The NHFR has the initial support of the General Sub-Directorate of Health Promotion and Epidemiology of the Ministry of Health, Social Services and Equality.

- It has been endorsed by chairpeople in charge of the Fragility Fracture Network (FFN) Hip Fracture International Registry.

- It is backed by 18 national and regional Scientific Societies from the field of Geriatrics, Traumatology and some multidisciplinary fields related to fractures and bone metabolism. (Annex 1).

- It has been classified by the Spanish Agency of Medicines and Medical Devices (AEMPS) as Non-PAS (a Non-Post-Authorization Study), and therefore the administrative procedure that governs it only includes the approval or ratification of the respective Institutional Review Boards (IRBs) of each site.

- It has been registered at the Spanish Agency for Data Protection.

\section{Distribution of tasks}

- A representative from each hospital: responsible for the local registry, including obtaining informed consent, guarantee of proper data collection and inclusion of cases, sending and safeguarding data.

- Data manager: in charge of collecting and compiling the cases from all the sites, data analysis and clean-up and drafting the results reports.

- Technical secretary: in charge of coordinating information and managing the correspondence between the participating hospitals and the scientific societies backing the project, achiving of documentation, and drafting a newsletter with periodic updates for all the participating sites. 
-The Investigative team will develop the following functions: design, implementation, follow-up, protection and monitoring of data and the information generated by the Registry. Coordination of the multicentre team. Research and analysis duties (direct or delegated to others requesting them). Management and implementation of auditing duties, definition of standards and proposal of objectives. Continual results assessment.

\section{Current situation}

The NHFR currently has 3,071 patient records from 48 hospitals, two quarterly reports have been drafted and it has been presented at the following 2017 congresses: Fragility Fracture Network (FFN), Spanish Society for Osteoporotic Fractures (SEFRAOS), Spanish Society for Geriatrics and Gerontology (SEGG), Spanish Society for Orthopaedic Surgery and Traumatology (SECOT), Madrid Society of Orthopaedic Surgery and Traumatology (SOMACOT, Spanish acronym), and the Catalan Society of Geriatrics and Gerontology (SCGIG, Catalan acronym).

\section{Call to potential participants.}

This publication serves to communicate the NHFR's desire to include the greatest possible number of cases of patients with fragility hip fractures throughout the entire Spanish territory. Physicians caring for patients with these characteristics can contact the Technical Secretariat at rnfc@bsj-marketing.es for their possible inclusion in the Registry. 


\section{Acknowledgments:}

This work was supported in part by a grant from AMGEN SA and UCB Biopharma. The sponsors were not involved in any aspect of the project nor in preparing the manuscript. Special thanks to Jesús Martín García from BSJ-Marketing for his administrative assistance.

\section{Disclosure statement:}

No potential conflicts of interest were disclosed. 


\section{References.}

1. Herrera A, Martínez AA, Ferrández L, Gil E, Moreno A. Epidemiology of osteoporotic hip fractures in Spain. Int Orthop 2006; 30: 11-4.

2. Alvarez-Nebreda ML, Jiménez AB, Rodríguez P, Serra JA. Epidemiology of hip fracture in the elderly in Spain. Bone 2008; 42: 278 -85.

3. Instituto de Información Sanitaria. Estadísticas comentadas: la atención a la fractura de cadera en los hospitales del SNS. Madrid.: Ministerio de Sanidad y Política Social 2010 [Último acceso septiembre 2016]. Disponible en: http://www.msps.es/estad Estudios/31stadísticas/cmbdhome.htm5

4. Ivergard M, Svedbom A, Hernlund E, Compston J, Cooper C, Stenmark J, et al. Epidemiology and economic burden of fractures in Spain. A report prepared in collaboration with the International Osteoporosis Foundation (IOF) and the European Federation of Pharmaceutical Industry Associations (EFPIA). Arch Osteoporos 2013; 8: 137; pags 195-202.

5. Azagra R, López-Expósito F, Martín-Sánchez JC, Aguyé A, Moreno N, Cooper C, et al. Changing trends in the epidemiology of hip fracture in Spain. Osteoporos Int 2014; 25: 1267-74.

6. González-Montalvo JI, Alarcón T, Mauleón JL, Gil-Garay E, Gotor P, Martín-Vega A. The orthogeriatric unit for acute patients: a new model of care that improves efficiency in the management of patients with hip fracture. Hip Int 2010; 20: 229-35.

7. Mears SC, Kates SL. A guide to improving the care of patients with fragility fractures, Edition 2. Geriatr Orthop Surg Rehabil 2015; 6: 58-120.

8. Bardales Mas Y, González Montalvo JI, Abizanda Soler P, Alarcón Alarcón MT. [Hip fracture guidelines. A comparison of the main recommendations]. Rev Esp Geriatr Gerontol 2012; 47: 2207.

9. Pioli G, Barone A, Mussi C, Tafaro L, Bellelli G, Falaschi P, et al. The management of hip fracture in the older population. Joint position statement by Gruppo Italiano Ortogeriatria (GIOG). Aging Clin Exp Res 2014; 26: 547-53.

10. Australian and New Zealand Guideline for Hip Fracture National Hip Fracture Database. National Report 2013. [Último acceso septiembre 2016]. Disponible en: http://www.nhfd.co.uk/20/hipfractureR.nsf/0/CA920122A244F2ED802579C900553993/\$file/NH FD\%20Report\%202013.pdf.

11. American Academic of Orthopaedics Surgeons (AOOS). Management of hip fractures in the elderly. Evidence based clinical practice Guideline. [Último acceso septiembre 2016]. Disponible en: http://www.aaos.org/Research/guidelines/HipFxGuideline.pdf.

12. NICE National Institute for Health and Care Excellence. Hip fracture overview. Available from: http://pathways.nice.org.uk/pathways/hip-fracture. Accessed December 8, 2014.

13. The care of patients with fragility fracture. The Blue Book. Published by the British Orthopaedic Association (BOABGS). London, 2007. Disponible en: http://www.bgs.org.uk/pdfcms/pubs/Blue\%20Book\%20on\%20fragility\%20fracture\%20care.pdf

14. Guía de buena práctica clínica en Geriatría. Anciano afecto de fractura de cadera. SEGG/SECOT 2007. [Último acceso septiembre 2016]. Disponible en http://www.segg.es/sites/default/files/page/guia_fractura_cadera.pdf 
15. Gomar Sancho F, González Macías J, Cassinello Ogea C, Carpintero Benítez P, Diez Pérez A (Editores). Libro Azul de la Fractura Osteoporótica en España de 2012. SEFRAOS 2012. ISBN: 978-84-695-3860-9

16. Caeiro JR, Bartra A, Mesa-Ramos M, Etxebarría I, Montejo J, Carpintero P, et al. Burden of first osteoporotic hip fracture in Spain: A prospective, 12-month, observational study. Calcif Tissue Int 2017; 100: 29 -39.

17. Sáez-López P, Martín Pérez E, González Ramírez A, Pablos Hernández C, Jiménez Mola S, Vuelta Calzada E, et al. Actividad ortogeriátrica en los hospitales públicos de Castilla y León: descripción y revisión de la literatura. Rev Esp Geriatr Gerontol 2014; 49: 137-44.

18. Sáez-López P, Brañas F, Sánchez-Hernández N, Alonso-García N, González-Montalvo JI. Hip fracture registries: utility, description, and comparison. Osteoporosis Int 2017; 28: 1157-66. |

19. Johansen A, Golding D, Brent L, Close J, Gjertsen JE, Holt G, et al. Using national hip fracture registries an audit databases to develop an international perspective. Injury Int J Care Injured 2017; 48: 2174-9.

20. Neuburger J, Currie C, Wakeman R, Tsang C, Plant F, De Stavola B, et al. The impact of a National Clinician-led Audit Initiative on care and mortality after hip fracture in England: an external evaluation using time trends in non-audit data. Med Care 2015; 53: 686-91.

21. Muñoz-Pascual A, Sáez-López P, Jiménez-Mola S, Sánchez-Hernández N, Alonso-García N, Andrés-Sainz AI, et al. Ortogeriatría: Primer registro multicéntrico autonómico de fracturas de cadera en Castilla y León (España). Rev Esp Geriatr Gerontol 2017; 52: 242-8.

22. Prieto-Alhambra D, Aguado-Maestro I, Cano IA, Barrés Carsi M, Brañas Baztán F, Bravo Bardají MF, et al. Impacto de la fractura de cadera en la calidad de vida en el momento del ingreso y al mes y cuatro meses de seguimiento: la cohorte prospectiva SPARE-HIP Rev Osteoporos Metab Mineral 2016; 8: 20.

23. Fragility Fracture Network hip fracture audit database. Minimum common dataset (MCD). Version 1.5 june 2014. [Último acceso septiembre 2016]. Disponible en http://fragilityfracturenetwork.org/ 


\section{Annex I. List of representatives, delegates and participating hospitals during the first year of the National Hip Fracture registry}

\section{Delegates for the National Scientific Societies}

Manuel Díaz Curiel - Fundación Hispana de Osteoporosis y Enfermedades del Metabolismo Óseo (Hispanic Foundation of Osteoporosis and Bone Metabolism Disorders, FHOEMO). Ricardo Larrainzar - Sociedad Española de Cirugía Ortopédica y Traumatología (Spanisch Society of Orthopaedic Surgery and Traumatology, SECOT). Juan Ignacio González Montalvo - Sociedad Española de Fracturas Osteoporóticas (Spanish Society of Osteoporotic Fractures, SEFRAOS). Alfonso González Ramírez - Sociedad Española de Geriatría y Gerontología (Spanish Society of Geriatrics and Gerontology, SEGG). José Ramón Caeiro - Sociedad Española de Investigación Ósea y del Metabolismo Mineral (Spanish Society of Bone and Mineral Metabolism Research, SEIOMM). Alfonso González Ramírez - Sociedad Española de Medicina Geriátrica (Spanish Society of Geriatric Medicine, SEMEG). Jose Luis Pérez Castrillón - Sociedad Española de Medicina Interna (Spanish Society of Internal Medicine, SEMI).

\section{Delegates for the Regional Scientific Societies}

Noelia Alonso García - Sociedad Castellano Leonesa Cántabro y Riojana de Traumatología (Society of Castille, Leon, Cantabria and Rioja of Traumatology; SCLECARTO). Pilar Mesa Sociedad Aragonesa de Geriatría y Gerontología (Socity of Aragon of Geriatrics and Gerontology, SAGGARAGON). Angélica Muñoz Pascual - Sociedad de Geriatría y Gerontología de Castilla y León (Society of Castille and Leon of Geriatrics and Gerontology, SGGCYL). Anabel Llopis Sociedad Catalana de Geriatría y Gerontología (Society of Catalonia of Geriatrics and Gerontology, SCGIG). Raquel Vállez - Sociedad Matritense de Cirugía Ortopédica y Traumatología (Society of Madrid of Orthopedic Surgery and Traumatology, SOMACOT). Jesús Mora Fernández - Sociedad Madrileña de Geriatría y Gerontología (Society of Madrid of Geriatrics and Gerontology, SMGG). Francisco Tarazona - Sociedad Valenciana de Geriatría y Gerontología Society of Valencia of Geriatrics and Gerontology, (SVGG). Raquel Ortés - Sociedad Extremeña de Geriatría y Gerontología (Society of Extremadura of Geriatrics and Gerontology, SOGGEX). Teresa Pareja - Sociedad Castellano Manchega de Geriatría y Gerontología (Society of Castille-La Mancha of Geriatrics and Gerontology, SCMGG). Marta Alonso - Sociedad de Geriatría y Gerontología del Principado de Asturias (Society of the Principality of Asturias of Geriatrics and Gerontology, SGGPA). José Ramón Caeiro - Sociedad Gallega de Cirugía Ortopédica y Traumatología (Society of Galicia of Orthopedic Surgery and Traumatology, SOGACOT). Vicente Canales - Sociedad Aragonesa de Cirugía Ortopédica y Traumatología (Society of Aragon of Orthopedic Surgery and Traumatology, SARCOT). Pedro Carpintero Sociedad Andaluza de Traumatología y Ortopedia (Society of Andalusia of Orthopedic Surgery and Traumatology, SATO). Inés Gil Broceño - Sociedad Murciana de Geriatría y Gerontología (Society of Murcia of Geriatrics and Gerontology, SMGG).

\section{Delegates for International Scientific Societies}

Colin Currie - Fragility Fracture Network (FFN).

\section{Representatives for each of the participating hospitals}

Sonia Jiménez Mola - Complejo Asistencial de León. María Cruz Macías - Complejo Asistencial de Segovia. Ana Andrés - Complejo Asistencial de Palencia. Anabel Llopis - Hospital de Mataró CSDM. Pilar del Pozo Tagarro - Hospital Santos Reyes de Aranda de Duero. Abelardo Montero Sáez - Hospital Universitari de Bellvitge. $\mathrm{M}^{\mathrm{a}}$ Carmen Cervera - Hospital Clínico Universitario de Valladolid. Mariano de Miguel Artal - Hospital Universitario Santa María / Arnau de Vilanova de 
Lleida. Montse Barceló - Hospital Santa Creu i Sant Pau. Francisco Suárez - Hospital Cruz Roja de Gijón. Elena Ubis Díez - Hospital Público Sagrado Corazón de Jesús, Huesca. Francisco Jiménez Muela - Hospital Monte Naranco de Oviedo. Ma Paz García Díaz - Hospital de Barbastro. Rebeca Fernández Regueiro - Hospital Universitario de Cabueñes, Gijón. Pilar Mesa - Hospital Provincial de Nuestra Señora de Gracia, Zaragoza. José Ramón Caeiro - Hospital Clínico Universitario de Santiago de Compostela. Guadalupe Lozano Pino - Hospital Virgen del Puerto de Plasencia. Teresa Pareja - Hospital Universitario de Guadalajara. Marta Osca Guadalajara Hospital Obispo Polanco de Teruel. Francisco Manuel García Navas - Hospital General Universitario de Ciudad Real. Raquel Bachiller - Hospital Universitario Nuestra Señora de Candelaria de Tenerife. Carmen Barrero Raya - Complejo Hospitalario de Toledo. Nuria Montero Fernández - Hospital General Universitario Gregorio Marañón. Natalia Sánchez Hernández Complejo Asistencial de Ávila. Fátima Brañas Baztán - Hospital Universitario Infanta Leonor de Madrid. Marta Neira Álvarez - Hospital Universitario Infanta Sofía de Madrid. Jesús Mora Fernández - Hospital Clínico Universitario San Carlos de Madrid. Marta Pérez García - Hospital Álvaro Cunqueiro de Vigo. Juan Ignacio González Montalvo - Hospital Universitario La Paz de Madrid. Raquel Vállez - Hospital Central de la Defensa Gómez Ulla de Madrid. M ${ }^{\mathrm{a}}$ Jesús Molina Hernández - Hospital Universitario Severo Ochoa de Leganés. Julia Illán - Hospital Universitario de Getafe, Madrid. Cristina González de Villaumbrosía - Hospital Rey Juan Carlos de Móstoles, Madrid. Inmaculada Boyano - Hospital Universitario de Móstoles, Madrid. Cristina Ojeda Thies - Hospital Universitario 12 de Octubre de Madrid. Isabel Pérez Millán - Hospital Universitario Ramón y Cajal de Madrid. José Salvador Barreda Puchades - Hospital de Manises. Marta Alonso Álvarez - Hospital Vital Álvarez-Buylla. José Manuel Cancio - CSS El Carme, Badalona Serveis Asistencials. Pablo Alejandro Blanco Alba - Hospital San Juan de Dios de Bormujos. Laura Puertas Molina - Hospital Universitari Mútua de Terrassa. María Prado Cabillas - Hospital de La Línea de la Concepción. Eugenia Sonia Sopena Bert - Hospital Sociosanitari Francoli. Berta Alvira Rasal - Hospital Universitario Infanta Elena de Valdemoro. José María Santiago - Hospital Moisés Broggi Consorci Sanitari Integral. Anabel Hormigo - Hospital Universitario Fundación Jiménez Díaz. Inés Gil Broceño - Complejo Hospitalario Universitario de Cartagena. Marisa Garreta Centre Fórum, Parc de Salut Mar, Barcelona. Enric Duaso - Consorcio Sanitario del Anoia, Hospital de Igualada. Nestor Pereira -Hospital de Lanzarote. Gracia Megías Baeza -Hospital Sagrado Corazón de Sevilla. Laura Alexandra Ivanov-Consorci Sanitari del GArraf. Verónica García Cárdenas -Hospital General de Villalba

\section{National coordinators and coordinators for the Autonomous Communities}

Pilar Sáez López - Coordinador Nacional. Juan Ignacio González Montalvo - Director del Grupo 27 de IdiPAZ, Centro Coordinador Nacional. Anabel Llopis - Coordinador de Cataluña. Pilar Mesa - Coordinador de Aragón. Teresa Pareja - Coordinador de Castilla La Mancha. Jesús Mora Fernández - Coordinador de la Comunidad de Madrid. Angélica Muñoz - Coordinador de Castilla y León. Francisco Tarazona - Coordinador de la Comunidad Valenciana. Marta Alonso Coordinador de la Comunidad del Principado de Asturias. Raquel Ortés - Coordinador de la Comunidad de Extremadura. Marta Pérez García - Coordinador de Galicia. Iñigo Etxebarria Foronda- Coordinador del País Vasco 
Table 1. List of variables of the National Hip Fracture Registry (NHFR) (adaptation with a reverse translation reviewed, from the dataset of the Fragility Fracture Network (FFN))

\begin{tabular}{|c|c|}
\hline \multicolumn{2}{|c|}{ A. HOSPITAL PHASE } \\
\hline 1.01 & Informed Consent (IC) yes / no \\
\hline 1.02 & Registry number \\
\hline 1.03 & Gender \\
\hline 1.04 & Age at the time of admission due to the fracture \\
\hline 1.05 & Autonomous Community / Postal Code \\
\hline 1.06 & Hospital code \\
\hline 2.01 & Prefracture place of residence: home, institutionalised, acute hospitalization, unknown \\
\hline 2.02 & Prefracture mobility: Modified FAC scale \\
\hline 2.03 & Preoperative Mental Evaluation. Validated spanish versión of the Pfeiffer Questionnaire \\
\hline 2.04 & ASA surgical risk grade (American Society of Anestesiologists) \\
\hline 2.05 & Side affected by the fracture \\
\hline 2.06 & Pathological fractures: malignancy / atypical \\
\hline 2.07 & $\begin{array}{l}\text { Type of fracture: non-displaced intracapsular, displaced intracapsular, intertrochanteric, } \\
\text { subtrochanteric, other }\end{array}$ \\
\hline 2.08 & $\begin{array}{l}\text { Bone protection drugs prior to the fracture: antiresorptives yes/no, osteoforming yes/no, calcium } \\
\text { yes/no, vitamin D yes/no, other antiostoporotic medication yes/no }\end{array}$ \\
\hline 3.01 & Date and time of admission to the emergency department \\
\hline 3.02 & Vital status at discharge: Alive, deceased pre-surgery, deceeased post-surgery \\
\hline 3.03 & $\begin{array}{l}\text { Type of surgery: nonsurgical, cannulated screws, slising hip screw, cephalomedullary nail, } \\
\text { hemiarthroplasty, total hip replacement, other }\end{array}$ \\
\hline 3.04 & Date and time of surgery \\
\hline 3.05 & Time from admission to surgery (hours) \\
\hline 3.06 & Type of Anesthesia: General, Spinal, Anaesthetic Block yes/no \\
\hline 3.07 & Pressure Ulcers grade II OR MORE developed during stay in hospital yes/no \\
\hline 3.08 & $\begin{array}{l}\text { Presence of a clinical physician (in the first } 72 \text { hours since admission): Geriatrics, Internal } \\
\text { Medicine, Other Specialist, Not seen, Unknown. }\end{array}$ \\
\hline 3.09 & $\begin{array}{l}\text { Mobilization of the first day: if the patient is mobilized from be don the day of surgery of the nect } \\
\text { day }\end{array}$ \\
\hline 4.01 & $\begin{array}{l}\text { Destination upon discharge: Home, Nursing Home, Acute Hospitalization, Rehabilitation Unit, } \\
\text { Long Term Care Facility, Deceased, Unknown }\end{array}$ \\
\hline 4.02 & Date of Discharge \\
\hline 4.03 & Length of Stay (hours) \\
\hline 4.04 & Bone-protection drugs upon discharge \\
\hline \multicolumn{2}{|r|}{$\begin{array}{l}\text { B. POST-HOSPITALIZATION PHASE } \\
\text { The following variables are recorded } 30 \text { days after admission to Traumatology du to hip fracture. It can } \\
\text { be done bu a follow-up visit or a telephone interview. An interval } 3 \text { days before or after the } 30 \text { days is } \\
\text { accepted for data retrieval }\end{array}$} \\
\hline 5.01 & Readmission related to the hip fracture: readmission due to orthopaedic surgery \\
\hline 5.02 & Repeat surgery in the 30 days following admission \\
\hline 5.03 & Alive at 30 days \\
\hline 5.04 & 30 day mobility - use the same classification as point 2.02 \\
\hline 5.05 & $\begin{array}{l}\text { Plave of residence at } 30 \text { days: Home, Nursing Home, Acute Hospitalization, Rehabilitation Unit, } \\
\text { Long Term Care Facility, Deceased, Unknown. }\end{array}$ \\
\hline 5.06 & $\begin{array}{l}\text { Bone protection drugs: if the patient is taking bone protecting medication } 30 \text { days following the } \\
\text { fracture }\end{array}$ \\
\hline
\end{tabular}


Figure 1: Timeline for the National Hip Fracture Registry

\section{Timeline for the National Hip Fracture Registry (RNFC)}

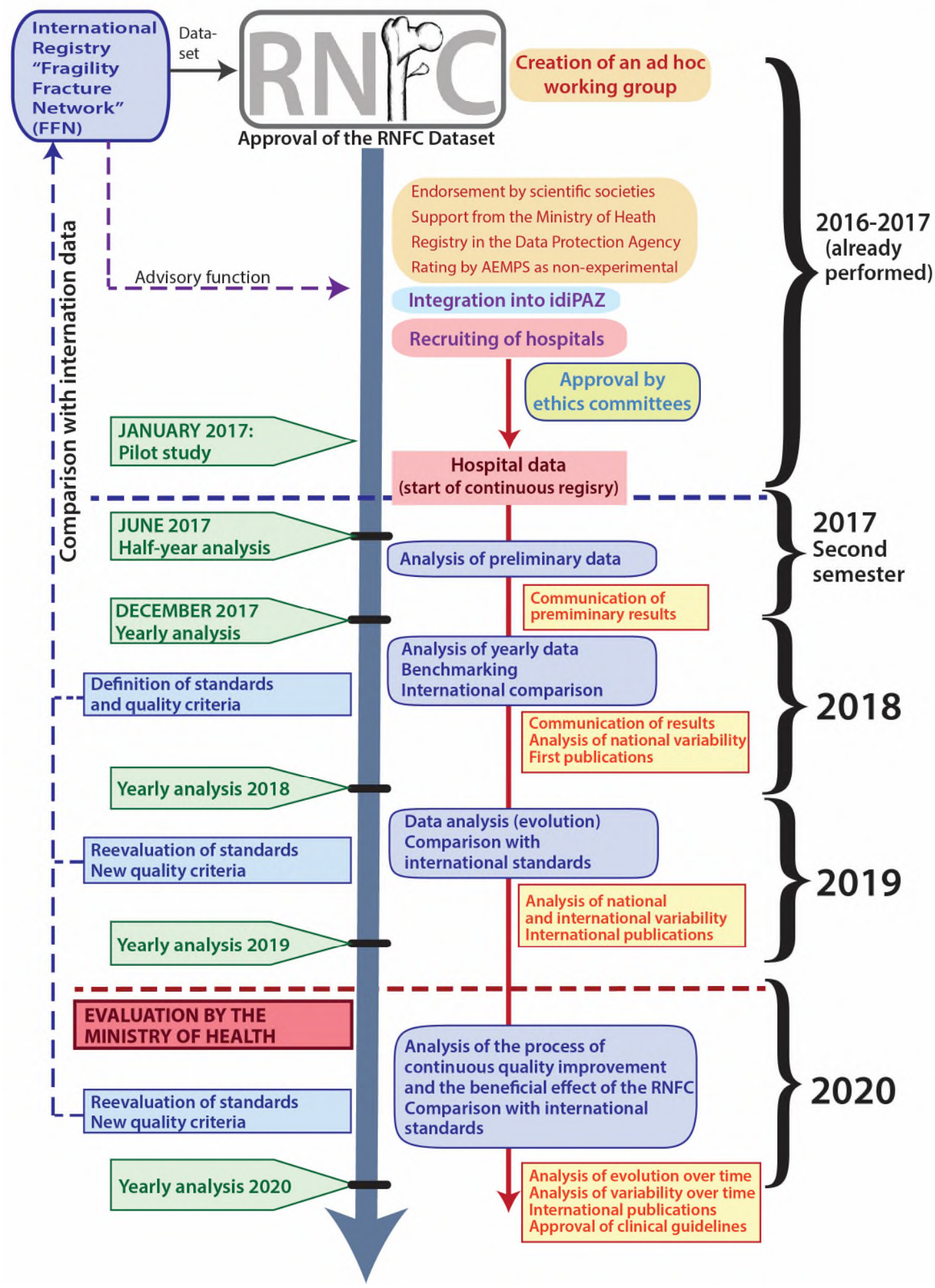

